\title{
RICE UNIVERSITY RADIOCARBON DATES I
}

\author{
BARRY F. BEC:K*
}

Department of Geology, Rice University, Houston, Texas 77001

The radiocarbon dating Iaboratory at Rice University forst became operative in the fall of 1970 . $A$ workable technique has been developed although operations are still in a state of flux. The benzene liquid scintillation counting method is used, the benzene being prepared as outlined by Noakes, Kim, and Akers (1967) with the following modifications. The CO. is further purified prior to storage and measuring by passing it through : gas bubblers containing potassium permanganate solution, silver nitrate solution, and a sulfuric acid-sodium dichromate solution (S. Valastro, pers. commun., 1970). Since no $C^{12} C^{133}$ analyses are available at present, to insure a complete reaction, both the $\mathrm{CO}$. generation and the C.II. gencration are continued for $1 / 2 \mathrm{hr}$ alter all visible signs of reaction have disappared.

After the trimerization of the acetylene to benzene, the benzene is parsed through a shiclded Dehydrite** trap prior to removal and bottling to remove residual water vapor previously found in minor quantities in the benzene. Polad (1969) noted that standard vials were unsuitable for low activity ambient temperature $\mathrm{C}^{11}$ counting; our experience verifies this. The only previous solution to this problem (ibid.) appeared economically unsuitable for our operation; conscquently, another technique for sealing the vials was developed. $\Lambda$ 'Iellon** disk is fitted to provide an ar-tight, unreactive scal.

The benzene is counted in a Beckman LS-100 soft beta spectrometer. NBS oxalic acid standards are prepared by wet oxidation, background standards prepared from Cretaceous El Abra Limestone, and samples are counted for 20 minute periods and recycled. An external standard ratio, which is a measure of quenching (Beckman Instruments, 1967), is automatically determined for each vial prior to the $\mathrm{C}^{1+4}$ counting. In some cases quenching was detected, probably due to chemical contaminants accumulating over long periods in the synthesis line and to minor variations in the counting vial geometry.

Despite the quenching we obtained useful data from the measurements. In many cases a quenched sample could be matched with an equally quenched oxalic-acid standard, thus assuring an equal machine efficiency for each count. Quenching was assumed equal when the external standard ratios were within 0.15 of each other (an average value for one standard deviation of the external standard ratio's distribution when the master gain control of the $\mathrm{IS}$ - 100 was set at 510 , as determined by the author). If the external standard ratios did not match within this limit, a quench correction was applied.

Ages are calculated using an Olivetti-Underwood Progamma 101

* Present address: Burcau of Water Mgt., Areal of Natural Resources, Dept. of P'ublic Works, Stop 23, Santurce, Pucrto Rico 00910.

** Registered trademark or copyrighted name. 
computer with a program suggested by Joln Noakes (pers. commun., 1970) utilizing raw count-rate clata and weights, based on the Iibby hall-life of 5508 years (Libby, 1955). 'I he standard error for an unquenched age determination is given as one standard deviation of the counting statistics. The error assigned to the quench-corrected age is given as the sum of the crrors which would be determined if the counting data for each of the two oxalic acid standards closest in quenching had been used. If the ages reported are quench corrected this is duly noted; samples which foll in the nonlinear portion of the quench-calibration curve were discarded. It is regrettable that quench correction was necessary but several check samples were dated in this manner and the answers were found satisfactory. In future it is hoped that both causes of quenching will be eliminated.

\section{A. Interlaboratory check samples}

Several interlaboratory check samples were clated at Rice University. Some samples were processed twice and some were counted several times.

\section{RU-44. Isla Cancun, NE Yucalan Peninsula, Mexico $999 \pm 254 *$}

Portion of large shell (Strombus gigas), coll. by W. C. Ward from $\mathrm{N}$ end of Isla Cancun (Punta Cancun) beneath $7.6 \mathrm{~m}$ of Cancun Folianite $\left(21^{\circ} 8^{\prime} \mathrm{N}\right.$ Iat, $86^{\circ} 45^{\prime} \mathrm{W}$ Long). Pieces of same shell were clated at 1030 $\pm 80 \mathrm{yr}$ 1.P. by ORINS and at $2700 \pm 110$ and $2730 \pm 75$ yr B.P. by ISUNO (W. C. Ward, pers. commun., 1970). Comment: age agrees with ORINS date, yet older I SUNO date is undoubtably correct since a midden occurring stratigraphically above the shell was dated at "250 в.c." (Andrews, 1969, p. 57). Since alteration of aragonite to calcite has generally caused shell ages from this area to appear younger (see p. 19I), outer, altered layers were possibly included to a greater extent in ORINS and RU samples than in LSUNO sample. The RU sample was acid rinsed, but not leached to any great extent since the shell appeared hard and unaltered. See also RU-46.

1) $1044 \pm 83$

RU-46. Isla Cancun, NE Yucatan Peninsula, Mexico 2) $837 \pm 81$ Another portion of same shell as RU-44. Comment: 1st age agrees perfectly with ORINS date and 2 nd age is very close.

\section{RU-48. Cancun Lagoon, NE Yucatan Peninsula,}

\section{Mexico}

$2098 \pm 239 *$

Shells (Codakia orbicularis), coll. by M. Brady (No. 86A) ca. $1.5 \mathrm{~m}$ below sediment surface in Cancun Lagoon $\left(21^{\circ} 5^{\prime} \mathrm{N}\right.$ Lat, $86^{\circ} 47^{\prime} \mathrm{W}$ Long). Several other Codakia orbicularis shells from same sample were dated at $2108 \pm 189$ yr B.P. by Mobil Oil Co. (H. Nelson, pers. commun., 1970-71). Comment: perfect agreement of the 2 dates.

* Quench corrected. 
RU-19. Isla Cancun, NE Yucatan Peninsula, Mexico

1) $3177 \pm 142$

2) $3231 \pm 76$

Shells (Codakia orbicularis) id. and coll. by M. Brady (No. 87C) in a core from $N$ chel of Isla Cancun ( $\left(91^{\circ} 8^{\prime} \mathrm{N}\right.$ Lat, $86^{\circ} 15^{\prime} \mathrm{W}$ Iong). Sevcral shells (1.ucina pemusylyania) from same sample were clated at 3087 \pm 188 yr B.P. by Mobil Oil Co. (H. Nelson, pers. Commun., 1970-71). Comment: 2 counts agree well and both agree with Mobil age.

\section{RU.50. Isla Cancun, NE Yucatan Peninsula, 1 1) $2949 \pm 89$ Mexico \\ 2) $2967 \pm 257 \%$}

Scparate portion identical to RU-19. Comment: 2 count-rate determinations atgree and both agrce with Mobil date. Samples RU-19 and -50 bracket Mobil determination.

\section{RU.55. Yalahau Lagoon, NE Yucatan \\ 1) $1051-231 *$ Peninsula, Mexico \\ 2) $1168-131$}

Shells (Chione cancellata) id. and coll. by M. Brady (No. 72B) in Yalahau Lagoon ca. $1.2 \mathrm{~m}$ below sediment surface $\left(21^{\circ} 32^{\prime} \mathrm{N}\right.$ Lat, $87^{\circ}$ 13' W Iong). Other Chione cancellata shells from same sample were dated at $181.1+195$ yr B.P. by Mobil Oil Co. (H. Nelson, pers. commun., 1970-71). Comment: discrepancy between Molsil and RU dates has no obvious cause; neither datte is invalidated by geologic context.

\section{RU-76. Cancun Lagoon, NE Yucatan Peninsula, $\quad \mathbf{5 1 2} \pm 155$ Mexico}

Gastropod and pelecypod shells coll. by M. Brady (No. 87B) ca. $1.5 \mathrm{~m}$ below sediment surface in Cancun I agoon (210 $8^{\prime} \mathrm{N}$ Iat, $86^{\circ} 45^{\prime}$ W long). Sample was scrubled and leached in HCl until outer $20 \%$ was removed. Mobil previously dated sample at $685 \pm 174$ yr B.P. and overlying interval ca. $1.2 \mathrm{~m}$ below surface at $946 \pm 185$ yr B.P. (H. Nelson. pers. commum., 1970-71). Comment: sample was measured near end of this project, indicating our techniques remained satisfactory, since age agrees well with Mobil date, within statistical limits. Inverted sequence of ages here may be due to an error in Mobil's determination of overlying date or a more complicated sedimentologic reason, e.g., mixing of shells by burrowing or differential settling.

\section{RU.78. Yalahau Lagoon, NE Yucatan Peninsula, $\quad 469 \pm 142$} Mexico

Gastropod and pelecypod shells coll. by M. Brady (No. H-82) in NW corner of Yalahau Iagoon ca. $2.3 \mathrm{~m}$ below water scdiment interface $\left(21^{\circ}\right.$ $30^{\prime} \mathrm{N}$ Lat, $87^{\circ} 24^{\prime} \mathrm{W}$ Long). Sample dated by Mobil at $354 \pm 171 \mathrm{yr}$ B.P. (H. Nelson, pers. commun., 1970-71). Comments (M.B.): Molsil clate appears very young for sample overlain by $2.3 \mathrm{~m}$ sediment; (B.B.): however, Rice date confirms this agc, within statistical limits. This sample also processed at finish of project and reconfirms agreement with other labs.

* Quench corrected. 


\section{B. NE Yucatan shore samples}

Behind backswamp of Isla Blanca Lagoon, 2 trails wind into jungle. Vegetation is tropical and very dense; gently undulating limestone topography is marked by rare small sinks ca. $3 \mathrm{~m}$ deep. Samples were coll. from limestone along these trails in order to date Pleistocene coastal accretion.

RU-56. Isla Blanca-A

Sample from large shell (Strombus gigas) coll. by B. Beck along $\mathrm{S}$ trail behind Isla Blanca Lagoon at backswamp shoreline $\left(21^{\circ} 19^{\prime} \mathrm{N}\right.$ Lat, $81^{\circ} 51^{\prime} W$ Long). Staining with Feigel's Solution showed shell to be principally aragonite $(95 \%,+)$ and therefore probably not significantly mineralogically altered.

\section{RU-57. Isla Blanca-B}

1) $27,147 \pm 2115$

2) $22,403 \pm 1375$

Gastropod and pelecypod shells from a marly coquina coll. by $\mathrm{B}$. Beck on surface ca. $1.6 \mathrm{~km}$ inland on $S$ trail behind Isla Blanca Lagoon $\left(21^{\circ} 19^{\prime} \mathrm{N}\right.$ Lat, $81^{\circ} 53^{\prime} \mathrm{W}$ I.ong). Shells were hard and lustrous and almost all matrix was removed in cleaning; staining with Feigel's Solution showed shells to be aragonite.

\section{RU-58. Isla Blanea-C}

1) $25,841 \pm 2485 *$

2) $27,464 \pm 2629$

Pelecypod shells from loosely cemented calcarenite coll. by M. Brady On surface ca. $1.6 \mathrm{~km}$ inland on $\mathrm{N}$ trail behind Isla Blanca Lagoon $\left(21^{\circ}\right.$ $22^{\prime} \mathrm{N}$ Lat, $81^{\circ} 54^{\prime} \mathrm{W}$ Long). Shells were hard and lustrous and loosely cemented matrix was readily removed in cleaning; staining with Fcigel's Solution showed shells to be aragonite and the matrix calcite.

\section{RU-59. Isla Blanca-D}

$12,289 \pm 2444^{*}$

Iarge piece of coral coll. by M. Brady along $\mathrm{N}$ trail behind Isla Blanca I agoon at backswamp shoreline ( $21^{\circ} 22^{\prime} \mathrm{N}$ Lat, $81^{\circ} 52^{\prime} \mathrm{W}$ Long). Specimen was much weathered and extremely porous (very low density), and contained soil in exterior pores. Exterior soil and outer portion of coral were removed in cleaning.

\section{RU-61. Isla Blanea-E}

$19,664 \pm 1303 *$

I arge piece of coral coll. by M. Brady ca. $2.9 \mathrm{~km}$ inland on $\mathrm{N}$ trail behind Isla Blanca Lagoon ( $21^{\circ} 22^{\prime} \mathrm{N}$ Lat, $81^{\circ} 54^{\prime} \mathrm{W}$ Long). Sample was highly weathered and soil-ridden but porosity was not as evident as in RU-59. Exterior soil and outer portion of coral were removed in cleaning.

\section{RU-62. Isla Blanca-F}

$18,144 \pm 495$

Whole-rock portion of marly coquina coll. by B. Beck on surface ca. $1.6 \mathrm{~km}$ inland on $\mathrm{S}$ trail behind Isla Blanca Lagoon $\left(21^{\circ} 19^{\prime} \mathrm{N}\right.$ Lat, $81^{\circ}$ $53^{\prime} \mathrm{W}$ Long); shells from same coquina were analyzed as RU-57. Staining with Feigel's Solution showed shells and some matrix to be aragonite but

* Quench corrected. 
some large amorphous areas of matrix were calcite. Comment: position and shape of calcitic areas suggested alteration by permeating water flow.

\section{RU.63. Isla Blanca-G}

$19,816 \pm 38.55 *$

Pelecypod and gastropod shells from marly coquina coll. by B. Beck ca. $1.6 \mathrm{~km}$ inland on $\mathrm{S}$ trail behind Isla l3lanca Lagoon $\left(21^{\circ} 19^{\prime} \mathrm{N}\right.$ Lat, $81^{\circ} 53^{\prime} \mathrm{W}$ I ong), ca. $90 \mathrm{~m}$ shoreward of RU-57. Matrix was difficult to remove and shells could only be partially cleaned; $<5 \%$ matrix contamination remained.

\section{RU-81. Isla Blanea-H}

$19,998 \pm 1135$

Another portion of large piece of coral, RU-61. Comment: date agrees perfectly with previous determination.

General Comment: since ocean waters are generally deficient in $\mathrm{C}^{11}$ with respect to the atmosphere, marine shells from surface waters generally give an age ca. 400 yr too old (Olsson, 1968); but for this study, $400 \mathrm{yr}$ is not significant compared to the statistical crror and we will neglect this correction. Taft and Harbangh (1964) list 1 methods of shell contamination: mixing of materials of various ages in the sample; assimilation of dead cabon from ancient limestone in solution and subsequent secretion of the carbon in shell material (hard-water effect); burrowing of organisms into previously formed, older sediments; and ingestion of older carbonate particles with food by shell secreting organisms. Postclepositional recrystallization of carbonate shell matcrial by ground water is also a possibility and could produce older dates by exchange with ancicnt limestone carbon or younger dates by exchange with modern atmospheric carbon.

Chappel (Polach el ai., I969, p. 261) states that "almost all recrystallized samples appear falsely young . . ." referring to a series of samples from uplifted reefs on the New Guinca coast.

Of the samples dated, the least altered gave the oldest dates, ca. 27,000 в.P. Another Strombus gigas sample from this general area was dated by I.SUNO at $30,225 \pm 1075$ B.P. (pers. commun., W. C. Ward, 1972 ). It is probible that the coastal limestone is ca. $30,000 \mathrm{yr}$ old and corresponds with the high sea-level stand ascribed by many authors to that time (Curray, 196.5; Shepard and Curray, 1967; Milliman and Emery, 1968).

\section{Isla Blanca Lagoon samples}

Isla Blanca is an elongated peninsula, ca. $25 \mathrm{~km}$ long and ca. 0.2 to $1.6 \mathrm{~km}$ across, extending $\mathrm{N}$-ward from, almost parallel to, coast of $\mathrm{NE}$ Yucatan. Protected from coastal wave action by this barrier, a large, shallow, quiet-water lagoon exists behind Isla Blanca. The sediment within the lagoon consists entircly of carbonates in the form of mud, sand, and some larger shell particles.

The coarse portion of the sediment is both allochthonous and autochthonous, and includes "echinoids, corals, coralline algae, hard-

* Quench corrected. 
pellets, coated grains, and lithoclasts which are not indigenous to the lagoon" (Brady, 1971, pt. IV, p. 29). The fine sediment is principally high strontium aragonite needles from Codiacean algae and is predominantly allochthonous (Brady, 1971). Since currents within the lagoon are slight, sedimentation occurs primarily near the mouth. The fine portion of the sediment was sampled along the length of the lagoon to date approximately the growth rate of the spit. Brady (1971) did not detect any significant mineralogic variation within the lagoon.

RU.68. Blanca Lagoon Surface Sediment-A $352 \pm 238 *$

Fine sediment from Brady's surface sample I.B. $59\left(21^{\circ} 26^{\prime} \mathrm{N}\right.$ Lat, $86^{\circ} 47^{\prime} \mathrm{W}$ Long). Secliment est:** $67 \%$ aragonite, $30 \%$ magnesium calcite, and $3 \%$ calcite (Brady, 1971).

\section{RU.69. Blanca Lagoon Surface Sediment-B}

$294 \pm 360 *$

Fine sediment from Brady's surfice sample I.B. $58\left(21^{\circ} 25^{\prime} \mathrm{N}\right.$ Lat, $86^{\circ} 47^{\prime} \mathrm{W}$ Long). Sediment est:** $68 \%$ aragonite, $29 \%$ magnesium calcite, and $3 \%$ calcite (Brady, 1971).

\section{RU-75. Blanca Lagoon Surface Sediment-C}

$656 \pm 238 *$

Fine scdiment from brady's surface sample I.B. $49\left(21^{\circ} 20^{\prime} \mathrm{N}\right.$ Lat, $86^{\circ} 48^{\prime} \mathrm{W}$ Long). Sediment est: $* 76 \%$ aragonite, $23 \%$ magnesium calcite, and 1\% calcite (Brady, 1971).

\section{RU-72. Blanca Lagoon Surface Sediment-D}

$1006 \pm 153 *$

Fine sediment from Brady's surface sample I.B. $43\left(21^{\circ} 15^{\prime} \mathrm{N}\right.$ Lat, $86^{\circ} 47^{\prime} \mathrm{W}$ I ong). Sediment est:** $78 \%$ aragonite, $21 \%$ magnesium calcite, and $1 \%$ calcite (Brady, 1971).

\section{RU-77. Blanca Lagoon Surface Sediment-E}

$1398 \pm 255 *$

Fine sediment from Brady's surface sample I.B. $40\left(21^{\circ} 12^{\prime} \mathrm{N}\right.$ Lat, $86^{\circ} 47^{\prime} \mathrm{W}$ Long). Sediment cst:** $57 \%$ aragonite, $41 \%$ magnesium calcite, and 2\% calcite (Brady, 1971).

General Comment: ages range from ca. 300 yr B.P. for the 2 samples which are probably actively accreting at the mouth of the lagoon to $1400 \mathrm{yr}$ B.P. for the innermost sample in the lagoon and the trend is distinct. If a normal marine correction of ca. $100 \mathrm{yr}$ is made, the sediment at the mouth of the lagoon is accreting at present. Dilution of the lagoon sediment by more recent adclitions will only increase the measured age gradient into the lagoon. Brady's (1971) theory of spit accretion is supported by these clates and the accretion rate appears rapid (ca. $25 \mathrm{~km} /$ $2000 \mathrm{yr}$ ). Aerial photographs support this or indicate it might be even more rapicl.

* All Blanca Iagoon surface samples were counted simultaneously and quenchcorrected with the same ideal relationship so that the difference between ages should have the most validity possible.

*: Estimated from strontium content (Brady, 1971). 
D. Miscellaneous dates from NE Yucatan

The dates below were processed to clarify ambiguities or inconsistencies in the information which M. Brady had gathered in his study of lagoonal sedimentation in NE Yucatan (Brady, 1971).

\section{RU.60. Blanca Lagoon Backswamp}

Peat fibers with shells (principally gastropod), shell hash, and caliche, coll. by M. Brady ca. $0.9 \mathrm{~m}$ below sediment surface in backswamp behind Isla Blanca Lagoon $\left(21^{\circ} 19^{\prime} \mathrm{N}\right.$ Iat, $81^{\circ} 50^{\prime} \mathrm{W}$ Iong). The sample was acidified with HCI and $\mathrm{COO}$.. was generated from the included carbonate portion, not the peat itself. Mobil Oil Co. previously dated peat at 1668 \pm 125 yr B.P. (H. Nelson, pers. commun., 1970-71). Comment: perfect agreement between the 2 dates is unexpected; caliche portion of sample was significant $(10-20 \%)$; this alone could alter date. Further study is needed.

\section{RU.73. Yalahau Lagoon \\ 1) $3623 \pm 179$} $25 \mathrm{~cm}$ below watcr-sediment interface in Yalahau Lagoon $\left(21^{\circ} 29^{\prime} \mathrm{N}\right.$ Lat, $87^{\circ} 9^{\prime} \mathrm{W}$ I.ong); coll. by M. Brady. Water depth over sample locality $3 \mathrm{~m}$. Comment (M.B.): date for sediment is approx. date of transgression of sea over matrsh.

\section{RU-74. Cancun Lagoon}

1) $3352 \pm 102$

2) $3105 \pm 153$

Pelecypod and gastropod shells; I Strombus gigas shell fragment comprised $3 / 1$ sample, coll. by M. Brady ca. $2 \mathrm{~m}$ below water sediment interface in Cancun I algoon (2 $1^{\circ} 6^{\prime} \mathrm{N}$ I at, $86^{\circ} 47^{\prime} \mathrm{W}$ Long). Sample was scrubbed and leached in HCil until outer $20 \%$ was removed. Mobil dated this interval at $660 \pm 174 \mathrm{yr}$ B.P. and overlying interval ca. $1.5 \mathrm{~m}$ below sediment surface at $2108 \pm 189$ yr B.P. (H. Nelson, pers. commun., 197071). Comment (M.B.): (late of overlying sediments fits geologic context. Mobil's date may be wong; RU date is more logical.

\section{RU-76. Canrun Lagoon}

Gastropod and pelecypod shells coll. by $\mathrm{M}$. Brady ca. $1.5 \mathrm{~m}$ below sediment surlace in Cancun Iagoon (2) $1^{\circ} 8^{\prime} \mathrm{N}$ Lat, $86^{\circ} 45^{\prime} \mathrm{W}$ Long). Sample was scrubbed and leached in HCI until outer $20 \%$ was removed. Mobil previously dated sample at $685+5174$ yr B.p. and overlying interval ca. 1.0101 .2 m below surface at $916 \pm 185$ yr B.P. (H. Nelson, pers. commun, 1970-71). Comment: RU date agrees with Mobil date within statistical limits; also reported as interlaboratory check sample.

\section{RU-78. Yalahan Lagoon \\ $469 \pm 142$}

Gastropod and pelecypod shells coll. by M. Brady in NW corner of Yalahau I agoon ca. 2.1 to 2.4 m below water-sediment interface $\left(21^{\circ} 30^{\prime}\right.$ N I alt, $87^{\circ} 2 \mathrm{I}^{\prime} \mathrm{W}$ Iong). Sample was dated by Mobil at $354 \pm 171 \mathrm{yr}$ B.P. (II. Nelson, pers. Commun,. 1970-71). Comments (M.B.): Nobil date 
appears too young for sampie overlain by ca. $2.4 \mathrm{~m}$ sediment; (B.B.): however, RU date agrees well within statistical limits; also reported as an interlaboratory check sample.

RFFFRYCIS

Andrews, E. W., IV, 1969. The archacological use and distribution of mollusca in the Maya lowlands: Middle America Researeh Inst. Pub. 34, Iulane Univ. New Or. leans.

Beckman Instruments. Inc., 1967. I S-100 liquid scintillation system and direct data readout module: Fullerton, California. Beckman Instruments, Inc., 103 p.

Braty, M., 1971, Sedimentology and diagenesis of carbonate muds in coastal lagoons of NF Yucatan: Ph.l), thesis, umpub., Rice Lniv., Houston, 'Texas.

Curray, I. R., I965, Iate Quaternary history, continental shelves of the United States, in: Wright, II. F. and Frey, 1). ( .., The Quatemary of the United States: Princeton, V.J., Princeton Unive Press, p. 729.73\%.

Libby, W. F., 1955, Radiocarbon dating: Chem. Brit., v. 5, no. 12, p. 548-552.

Milliman. J. D) and Fincry, K. O.. 1965, Sea levels during the past 35,000 years: Science, v. 162, p. 1121-1123.

Noakes, John, Kim. S. M. and thers, L. K., 1967, Recent improvements in benzene chemistry for radiocarbon dating: Coochim. ct Cosmochim. Acta, v. 31, p. 10941096 .

Olsson, I. U., 1968, Modern aspects of racliocarbon dating: Farth-Science Reviews, v. 4. D. $203-218$

Polach, H. A., 1969, Optimisation of lifpuid scintillation radiocarbon age determinations and reporting of ages: Atomic Encogy in Australia, v. 12, no. 3, p. 21-28.

Polach, H. A., Chappell, J., and Iovering. J. F., 1969, ANU radiocarbon date list III: Radiocarbon, v. 11, p. $215-262$.

Shepard, F. P. and Cultay, J. R., 1967, Carbon-l4 determination of sea level changes in stable areats: in: Progress in Occanography, v. 4, The Quaternary history of the ocean hasins, Oxford, Pergamon Press. p. 283-291.

Taft, W. H. and Jarbaugh, J. W., 1964, Modern carbonate sediments of Southern Florida, Bahamas, and Espiritu Santo Jsland, Baja, California: a comparison of their mineralogy and chemistry: Stanford Univ. Pubs., Geol. Sci., v. 8, no. 2, 133 p. 